\title{
EVALUASI PROGRAM PELAKSANAAN PENGELOLAAN USAHA BOGA DI SMK NEGERI 5 DENPASAR
}

\author{
N.W.Sugi Astika Dewi ${ }^{1}$, C.Istri Raka Marsiti ${ }^{2}$, L.Masdarini ${ }^{3}$ \\ Program Studi Pendidikan Kesejahteraan Keluarga, Jurusan Teknologi Industri, \\ Fakultas Teknik dan Kejuruan \\ Universitas Pendidikan Ganesha \\ Singaraja, Indonesia \\ e-mail : sugiastikadewi13@gmail.com¹, raka.marsiti@undiksha.ac.id ${ }^{2}$, \\ masdarini@undiksha.ac.id ${ }^{3}$
}

\begin{abstract}
Abstrak
Penelitian ini bertujuan untuk (1) mendeskripsikan pelaksanaan pengelolaan usaha boga di SMK Negeri 5 Denpasar (2) mengevaluasi program pelaksanaan pengelolaan usaha boga di SMK Negeri 5 Denpasar ditinjau dari segi konteks (Context), masukan (input), proses (process), hasil (product), keluaran (outcome). Jenis penelitian ini adalah penelitian Evaluatif dengan menggunakan model evaluasi CIPPO. Penentuan sampel menggunakan teknik purposive sampling sesuai dengan kebutuhan peneliti berjumlah 85 orang siswa. Data dikumpulkan melalui wawancara, angket dan studi dokumen. Data dianalisis secara desriptif kualitatif. Untuk menentukan kualitas program, data terlebih dahulu dianalisis menggunakan skor standar atau Z-Score yang selanjutnya ditransformasikan ke dalam T-Score kemudian dikonversi ke dalam kuadran Glickman. Hasil penelitian ini menunjukkan bahwa (1) Pelaksanaan pengelolaan usaha boga tersebut dilihat dari hasil wawancara diperoleh data bahwa pelaksanaan pengelolaan usaha boga masih mengalami beberapa kendala dalam hal persiapan bahan dan peralatan, pengolahan, pengemasan dan pemasaran produk sehingga setelah dianalisis menghasilkan pelaksanaan pengelolaan usaha boga sudah berlangsung cukup efektif, (2) Evaluasi program pelaksanaan pengelolaan usaha boga di SMK Negeri 5 Denpasar segi context berada pada kategori efektif, segi input berada pada kategori efektif, segi process berada pada kategori tidak efektif, segi product berada pada kategori tidak efektif, dan segi outcome berada pada kategori efektif.
\end{abstract}

Kata kunci : Evaluasi program, pengelolaan usaha boga, CIPPO, Glickman.

Abstract

This research was aimed at 1) describing the implementation of culinary business management at SMK Negeri 5 Denpasar, 2) evaluating the implementation of culinary business management at SMK Negeri 5 Denpasar viewed from context, input, process, product, and outcome. This is an evaluative research with CIPPO evaluation model. 85 students were taken as the samples of the study by applying purposive sampling technique. The data were gathered by using interview, questionnaire and documents study. The data were analysed descriptive-qualitatively. In order to determine the quality of the program, the data were firstly analysed by using standard scores or Z-score which were then transformed into T-score and converted into Glickman quadran. The results of the study show that 1) based on the interview results, it is found out that there were still some obstacles/problems along the implementation of culinary business management on the preparation and utensils, processing, packaging, and marketing of the product. The result of the analysis shows that the culinary business management was effectively implemented, 2) the evaluation of the implementation of culinary business management at SMK Negeri 5 Denpasar in terms of context is in the effective category, in terms of input is in the effective category, in terms of process is in the ineffective category, in terms of product is in the ineffective category, in terms of outcome is in the effective category.

Keywords: Program evaluation, Catering business management, CIPPO, Glickman. 


\section{PENDAHULUAN}

Mata pelajaran pengelolaan usaha boga adalah pengaturan suatu kegiatan penyelenggaraan di bidang makanan dan minuman dalam jumlah yang banyak dan diselenggarakan secara komersial. Sesuai dengan sifatnya yang komersial maka tujuan dari pengelolaan usaha boga adalah untuk mendapatkan keuntungan sesuai dengan prinsip ekonomi, (Endah Saraswati, M.M., dkk, 2016:7). Selain itu mata pelajaran usaha boga adalah salah satu mata pelajaran yang melibatkan siswa secara langsung untuk belajar berwirausaha sejak dini, karena pada mata pelajaran ini siswa diajarkan bagaimana cara mengelola sebuah usaha. Mulai dari tahap persiapan bahan dan peralatan, teknik pengolahan, pengemasan, pemasaran, serta bagaimana cara menghitung harga jual sehingga usaha jasa boga memperoleh keuntungan sesuai dengan tujuan utama untuk berwirausaha.

Berdasarkan struktur kurikulum SMK tahun 2013 revisi 2018 mata pelajaran pengelolaan usaha boga yang akan dipelajari di kelas XII semester 1 dan semester 2. Dalam mata pelajaran pengelolaan usaha boga kompetensi dasar yang akan dipelajari di semester 1 antara lain: (1) menganalisis jenis usaha boga dan merencanakan usaha boga serta menentukan jenis usaha boga yang dapat dikembangkan berdasarkan kebutuhan konsumen, (2) menganalisis prosedur pembelian bahan makanan dan melakukan pembelian bahan makanan (3) menerapkan penerimaan, penyimpanan bahan makanan, melakukan penerimaan dan penyimpanan bahan makanan, (4) menerapkan administrasi pembelian, penerimaan dan penyimpanan bahan makanan serta membuat administrasi pembelian, penerimaan dan penyimpanan bahan makanan, (5) mengevaluasi produksi produk usaha jasa boga dan melakukan produksi usaha boga.

Sedangkan kompetensi dasar yang akan dipelajari di semester 2 antara lain (1) mengevaluasi pengemasan produk jasa boga dan melakukan pengemasan produk usaha boga, (2) menghitung harga pokok produksi harga jual dan titik impas serta menggunakan hasil perhitungan harga jual dan titi impas untuk mengevaluasi keuntungan usaha jasa boga, (4) menganalisis teknik promosi dan pemasaran produk usaha boga serta melakukan promosi dan pemasaran produk, (4) mengevaluasi laporan hasil usaha boga serta membuat laporan usaha jasa boga, (Silabus PUB SMK Negeri 5 Denpasar). Praktik pengelolaan usaha boga akan dilaksanakan di semester 2 setelah semua materi pelajaran pengelolaan usaha boga disampaikan oleh guru.

Berdasarkan hasil observasi dan wawancara yang dilakukan pada tanggal 30 November 2018 dengan lbu Ni Komang Citra Dewi, S.Pd dan Ibu Sri Rejeki, S.Pd selaku pengampu mata pelajaran pengelolaan usaha boga diperoleh hasil yaitu, hasil penjualan tiap produk kue yang dibuat oleh siswa tidak pernah memenuhi target penjualan. Hal ini dapat dilihat pada data hasil penjualan produk yang diperoleh pada seluruh siswa kelas XII Jasa Boga di SMK Negeri 5 Denpasar Tahun Pelajaran 2017/2018.

Pengelolaan usaha boga sistem pengembangan produk dan produksinya semua dilakukan oleh siswa mulai dari tahap persiapan, pengolahan, pengemasan hingga pemasaran produk. Tahap persiapan yang dilakukan oleh siswa yaitu mulai dari persiapan bahan dan peralatan, kemudian dilanjutkan ke tahap pengolahan yang dilakukan sesuai dengan resep standar. Pada tahap pengemasan siswa merasa kesulitan karena kurang memiliki pengalaman dalam pengemasan kue yang konsistensi dari masing-masing kue yang dibuat berbeda sehingga kemasan produk menjadi kurang menarik. Dalam pemasaran produk tidak terlalu luas yaitu hanya di lingkungan sekolah saja, adanya saingan antara kelompok lain, selain adanya saingan antar kelompok kurangnya rasa percaya diri siswa untuk berjualan sangat berpengaruh terhadap hasil penjualan. Adapun upaya telah dilakukan oleh siswa agar produk yang dibuat habis terjual yaitu membeli sendiri produk yang jual, tetapi upaya yang telah dilakukan siswa tersebut tidak dapat 
memenuhi target penjualan yang sudah ditentukan sebelumnya.

Berdasarkan data penjualan hasil produksi produk pengelolaan usaha boga siswa kelas XII Jasa Boga SMK Negeri 5 Denpasar Tahun Pelajaran 2017/2018 terlihat persentase angka penjualan selalu tidak mencapai target yang telah ditentukan. Dari menu pertama hanya mencapai angka $70 \%$ begitupun pada menu berikutnya tidak pernah mencapai target $100 \%$, tentu saja angka tersebut cukup memprihatinkan, apalagi dengan latar belakang pelajaran pengelolaan usaha boga diharapkan siswa dapat menjadi pribadi yang mandiri untuk berwirausaha. Dengan adanya target penjualan produk yang ingin dicapai, maka guru dapat mengetahui kemampuan siswa dalam menawarkan produk yang dijual kepada konsumen.

Melihat data hasil penjualan produk yang tidak pernah mencapai target maka perlu adanya evaluasi terhadap pelaksanaan pengelolaan usaha untuk mengetahui apa yang menyebabkan hasil penjualan produk pengelolaan usaha boga tidak pernah mencapai target penjualan yang telah ditentukan yaitu dengan cara mengevaluasi program tersebut mulai dari proses pembelajaran dikelas sampai pelaksanaannya. Evaluasi adalah suatu proses kegiatan pengumpulan data, analisis data dan penarikan kesimpulan berdasarkan suatu acuan kriteria tertentu. Sedangakan program adalah suatu kegiatan yang dirancang untuk melaksanakan kebijakan dan dilaksanakan untuk waktu yang tidak terbatas atau berkesinambungan. Evaluasi program adalah serangkaian kegiatan yang bertujuan untuk mengukur keberhasilan sesuatu yang telah direncanakan atau diprogramkan sebelummnya.

Dalam penelitian ini model evaluasi program yang digunakan adalah model evaluasi CIPP, model ini sekarang sudah disempurnakan dengan satu komponen $\mathrm{O}$, singkatan dari outcome sehingga menjadi model CIPPO yang dikembangkan oleh Stufflebeam (1971) dan Shinkflied (1985) di Ohio State University. Stufflebeam dan Shinkflied merupakan dua tokoh terkemuka pendukung model evaluasi berorientasi pada pengambilan keputusan. Mereka berpendapat bahwa evaluasi merupakan sebuah proses menjelaskan, memperoleh, dan menyediakan informasi yang berguna bagi pengambilan sebuah keputusan yang terbaik. CIPPO yang merupakan sebuah singkatan dari huruf awal lima buah suku kata yaitu: Context evaluation (evaluasi terhadap konteks), Input evaluation (evaluasi terhadap masukan), Process evaluation (evaluasi terhadap proses), Product evaluation (evaluasi terhadap produk), Outcome evaluation (evaluasi terhadap dampak) (Arikunto, 2014:46). Penggunaan model evaluasi CIPPO dalam penelitian ini adalah berdasarkan permasalahan di atas maka perlu diadakan evaluasi terhadap program pelaksanaan pengelolaan usaha boga yang ada di SMK Negeri 5 Denpasar. Evaluasi dalam hal context yaitu bagaimana cara guru menyampaikan materi mata pelajaran pengelolaan usaha boga, input bagaimana siswa menerima pelajaran yang disampaikan oleh guru, process bagaimana pelaksanaan pengelolaan usaha boga dan siapa saja yang terlibat didalamnya, product bagaimana hasil produk pengelolaan usaha boga yang dibuat oleh siswa, outcome (dampaknya) bagaimana dampak yang timbul setelah siswa mengikuti pelajaran pengelolaan usaha boga. Sehingga diharapkan setelah adanya evaluasi ini guru dapat digunakan untuk memperbaiki kendala atau hambatan pada setiap program yang dihadapi siswa selama proses pembelajaran berlangsung.

Penelitian ini didukung oleh penelitian yang diteliti oleh Nyoman Suarjana, Universitas Pendidikan Ganesha tahun 2015 dengan judul Evaluasi Pelaksanaan Program Pusat Kegiatan Belajar Masyarakat (PKBM) di Kecamatan Gerokgak Kabupaten Buleleng. Hasil Penelitian ini menunjukkan bahwa, (1) Hasil evaluasi terhadap pengelenggaraan program PKBM di kecamatan gerokgak dengan menggunakan evaluasi program model CIPP diperoleh hasil sangat efektif, (2) 
Kendala-kendala yang dihadapi dalam penyelenggaraan program PKBM di kecamatan gerokgak dan rendahnya minimnya pengetahuan Stake holder tentang misi program, keberadaan sarana dan prasarana, proses pengelolaan program proses kerjasama dan partisipasi, kecakapan hidup, dan prestasi akademik. Upaya yang dapat dilakukan untuk menanggulangi kendala-kendala tersebut adalah dengan penggalian dukungan masyarakat, perbaikan cara pandang masyarakat, pensosialisasian program, pengaturan peralatan, bahan, dan ruang belajar, perencanaan anggaran, pengadaan alat, bahan, dan ruang belajar secara bertahap.

Berdasarkan latar belakang masalah yang telah diuraikan di atas, maka penulis tertarik untuk melakukan penelitian dengan judul "Evaluasi Program Pelaksanaan Pengelolaan Usaha Boga di SMK Negeri 5 Denpasar".

\section{METODE}

Pelaksanaan penelitian dan pengambilan data dalam penelitian ini dilakukan pada hari Senin, 22 April 2019 sampai dengan hari Kamis, 25 April 2019. Tempat penelitian adalah di SMK Negeri 5 Denpasar

Penelitian ini merupakan penelitian evaluasi program yang menggunakan model CIPPO yang dikembangkan oleh Stufflebeam. Model CIPPO digunakan untuk mengevaluasi pelaksanaan pengelolaan usaha boga yang ditinjau dari context, input, process, product serta (outcome) dampaknya wirausaha. Dalam penelitian ini evaluasi bertujuan untuk mengevaluasi pelaksanaan pengelolaan usaha boga di SMK Negeri 5 Denpasar dan kendala-kendala yang dihadapi serta alternatif penyelesaiannya sehingga diperoleh informasi secara komprehensif tentang pelaksanaan pengelolaan usaha boga di SMK Negeri 5 Denpasar. Jenis penelitian ini adalah penelitian evaluatif dengan analisis deskriptif kualitatif.

Analisis deskriptif dalam penelitian ini digunakan untuk memecahkan masalah dengan cara memaparkan atau menggambarkan apa adanya hasil penelitian. Sedangkan analisis kualitatif digunakan memaparkan data yang diperoleh berupa (gambar, angka) tidak dituangkan dalam bentuk bilangan angka atau statistik melainkan dalam bentuk kalimat. Dalam penelitian ini evaluasi pelaksanaan pengelolaan usaha boga di SMK Negeri 5 Denpasar yang meliputi context, input, process, product, dan outcome menggunakan metode kualitatif didukung dengan data kuantitatif. Dalam penelitian ini pengumpulan data dan informasi dikumpulkan dari responden dengan menggunakan wawancara dan kuesioner. Data hasil wawancara kemudian didukung dengan data kuantitatif dari hasil penyebaran kuesioner kepada siswa guna mendapatkan informasi yang komprehensif.

Populasi dalam penelitian ini adalah seluruh siswa kelas XII Jasa Boga SMK Negeri 5 Denpasar yang berjumlah 174 siswa. Namun untuk pengambilan sumber informasi ditentukan hanya 85 siswa di kelas jasa boga SMK Negeri 5 Denpasar. Sampel dalam penelitian ini akan dipilih dari 5 kelas XII Jasa Boga SMK Negeri Denpasar. Didasarkan atas definisi purposive sampling maka ditentukan sampel sebagai berikut. Diambil 2 orang tiap kelas untuk mendapatkan data wawancara pelaksanaan pengelolaan usaha boga dari 5 kelas yang ada, sehingga total sampel untuk memperoleh data wawancara berjumlah 10 orang siswa. Kemudian setelah mendapatkan data wawancara dilanjutkan ketahap berikutnya yaitu penyebaran kuesioner sebanyak 15 orang tiap kelas (rangking $1 \mathrm{~s} / \mathrm{d}$ rangking 15) untuk mendapatkan data evaluasi program pelaksanaan pengelolaan usaha boga di SMK Negeri 5 Denpasar, sehingga total sampel 
untuk memperoleh data kuesioner berjumlah 75 siswa.

Adapun prosedur dalam penelitian ini adalah sebagai berikut. (1) Mengidentifikasi adanya permasalahan yang signifikan untuk dipecahkan melalui metode deskriptif. (2) Merumuskan dan membatasi permasalahan. (3) Menentukan tujuan dan manfaat penelitian. (4) Melakukan studi pustaka yang berkaitan dengan permasalahan. (5) Mendesain metode penelitian yang akan digunakan termasuk dalam hal ini adalah menentukan populasi, teknik pengumpulan data, instrumen penelitian dan analisis data. (6) Uji coba instumen. (7) Pengambilan data dengan menyebarkan kuesioner pada sampel penelitian. (8) Menganalisis data. (9) Penyusunan laporan.

Adapun metode pengumpulan data pada penelitian ini menggunakan 3 (tiga) metode yaitu wawancara, studi dokumen, kuesioner. Wawancara dalam penelitian ini digunakan untuk mendapatkan data tentang bagaimana pelaksanaan pengelolaan usaha boga yang ada di SMK Negeri 5 Denpasar. Wawancara akan dilakukan dengan siswa kelas XII Jasa Boga yang sudah mengikuti mata pelajaran pengelolaan usaha boga. Studi dokumen dalam penelitian ini dilakukan dengan mengumpulkan dokumen-dokumen terkait meliputi silabus, data hasil penjualan produk pengelolaan usaha boga, data jumlah siswa. Selain itu juga digunakan untuk memperkuat bukti hasil penelitian. Penggunaan kuesioner (angket) dalam penelitian ini nantinya akan disebar ke 75 responden bertujuan untuk memperoleh data tentang evaluasi program pelaksanaan pengelolaan usaha boga yang ada di SMK Negeri 5 Denpasar. Data masih dalam bentuk kuantitatif (angka) yang nantinya akan dikonversi menjadi Tskor dengan teori kuadran Glickman.

Hasil dari perhitungan validitas isi dengan menggunakan rumus formula Gregory adalah 0,98. Maka evaluasi program pelaksanaan pengelolaan usaha boga memiliki validasi sangat baik. Hasil uji validitas butir variabel context, input, process, product, dan oucome menunjukkan semua soal valid. Dengan $r$ hitung $>0,2199$. Sedangkan reliabilitas tes menunjukkan variabel context, input, process, product, dan oucome memiliki reliabilitas yang tinggi.

Dalam penelitian ini data hasil wawancara dianalisis menggunakan analisis data deskriptif kualitatif sedangkan data yang diperoleh menggunakan kuesioner dianalisis dengan mengubah skor yang diperoleh ke dalam skor baku (ZSkor) dan menjadi T Skor. Kemudian hasil tersebut dikelompokkan berdasarkan kriteria CIPPO yang diadaptasi dari teori glickman.

\section{HASIL DAN PEMBAHASAN Hasil}

Berdasarkan hasil wawancara yang dilakukan kepada 10 orang yang diambil 2 orang tiap kelas (rangking terendah) siswa kelas XII Jasa Boga SMK Negeri 5 Denpasar hal tersebut didasari untuk mengefesiensi waktu dalam pengambilan data mengenai pelaksanaan pengelolaan usaha boga, diperoleh hasil dari segi context bahwa, sebelum memulai pembelajaran, guru menyampaikan tujuan pembelajaran dan materi pembelajaran terlebih dahulu. Menurut siswa, tujuan pembelajaran yang disampaikan diawal pembelajaran sangat penting agar siswa memahami pembelajaran yang akan dilaksanakan, sehingga siswa dapat mencapai tujuan Pembelajaran tersebut. Pihak sekolah sangat mendukung pembelajaran pengelolaan usaha boga dengan menyediakan fasilitas-fasilitas pendukung praktik mulai dari alat dan bahan. Fasilitas yang disediakan lengkap, agar memudahkan siswa dalam belajar. Apabila dilihat dari segi input bahwa, pembelajaran yang diberikan didahului dengan teori mengenai pengelolaan usaha boga. Setelah memiliki cukup teori dasar, siswa mempraktikkan teori tersebut agar lebih menguasai keterampilan pengelolaan usaha boga secara lebih mendalam. Setiap siswa selalu memperhatikan penjelasan yang disampaikan oleh guru sehingga pembelajaran yang disampaikan dapat dipahami siswa dengan baik.

Dilihat dari segi process bahwa, sebelum melakukan praktik pengelolaan usaha boga, siswa dibagi menjadi 
beberapa kelompok yang terdiri dari 4 sampai 5 orang siswa. Selanjutnya siswa secara berkelompok merekap semua bahan yang akan digunakan, kemudian diserahkan kepada guru. Guru selanjutnya melakukan pemesanan (pengamprahan) kepada kepala program keahlian tata boga. Ketika praktik telah dilaksanakan oleh masing-masing kelompok, apabila terjadi kegagalan dalam pembuatan produk, maka siswa melakukan konsultasi dengan guru untuk mengetahui letak kesalahannya, kemudian membuat ulang sampai berhasil. Pada pembuatan produk siswa harus mengikuti setiap langkah kerja untuk membuat suatu produk yaitu mulai dari tahap persiapan bahan dan peralatan, tahap pengolahan, tahap pengemasan/penyajian sampai tahap pemasaran. Maka hal ini dapat mencengah terjadinya kegagalan dalam membuat produk.

$\mathrm{Di}$ lihat dari segi product hasil penjualan produk pengelolaan usaha boga tidak pernah mencapai target penjualan. Hal ini dapat terjadi karena tahap pembuatan produk tidak sesuai dengan resep standar/baku dimana saat siswa menimbangan bahan terkadang bisa lebih dan bisa kurang. Dalam pengemasan produk beberapa siswa terkadang mengalami kesulitan karena konsistensi dari masing-masing produk berbeda, maka dalam hal ini perlu dikonsultasikan dengan guru mata pelajaran pengelolaan usaha boga, sehingga hasil yang diharapkan dapat diperoleh secara maksimal. Kesalahan yang dilakukan oleh siswa juga dapat menyebabkan kerugian sehingga hal ini dapat mempengaruhi target penjualan produk yang sudah ditentukan sebelumnya.

Dilihat dari segi outcome setelah mengikuti pembelajaran pengelolaan usaha boga yang diperoleh siswa memberikan motivasi berwirausaha kepada siswa karena dapat menghasilkan uang sendiri dan membuka peluang usaha sendiri. Siswa juga mendapatkan bekal pengetahuan tentang penjualan sebagai modal berwirausahanya.

Dalam studi dokumen, adapun beberapa dokumen yang diamati adalah dokumen-dokumen yang berkaitan dengan pelaksanaan pengelolaan usaha boga di SMK Negeri 5 Denpasar terutama yang berhubungan dengan context (silabus pengelolaan usaha boga, input (data siswa), process (manajemen pengelolaan usaha boga, kendala atau hambatan pengolahan), product (hasil penjualan produk). Dilihat dari hasil penjualan produk tidak pernah mencapai target penjualan yang telah ditentukan pada setiap jenis kue mulai dari bolu karamel sampai dengan puding marmer, outcome (dampak serta manfaat setelah mengikuti mata pelajaran PUB).

Berdasarkan uraian data hasil wawancara dan strudi dokumen di atas yang dilihat dari segi context, input, process, product, dan outcome pelaksanaan pengelolaan usaha boga di SMK Negeri 5 Denpasar sudah berlangsung dengan cukup efektif.

Untuk mengevaluasi program pelaksanaan pengelolaan usaha boga di SMK Negeri 5 Denpasar, kuesioner disebar kepada 75 orang siswa. Hasil angket tersebut selanjutnya dihitung sesuai dengan model CIPPO (context, input, process, product, dan outcome) dianalisis dengan skala likert kemudian dikonversi ke teori kuadran Glickman sehingga evaluasi program pengelolaan usaha boga dapat diketahui berada dalam kategori apa. Adapun hasil evaluasi tersebut adalah sebagai berikut.

Berdasarkan hasil evaluasi context menggunakan kuadran glickman, diperoleh hasil sesuai tabel 1 berikut ini.

Berdasarkan tabel diberikut, diperoleh hasil bahwa hasil t-skor dengan kategori positif berjumlah 40 orang dari 75 orang responden sedangkan t-skor dengan kategori negatif berjumlah 35 orang dari 75 orang responden. Berdasarkan hasil tersebut, karena jumlah t-skor dengan

Tabel 1 Hasil Evaluasi Context

\begin{tabular}{lllcc}
\hline \multirow{2}{*}{ Variabel } & \multicolumn{1}{c}{ Indikator } & \multicolumn{2}{c}{ t-skor } & Hasil \\
\cline { 2 - 2 } Context & Sositif & Negatif & \\
\cline { 2 - 2 } & Silabus & \multirow{2}{*}{40} & 35 & + \\
\cline { 2 - 2 } & Dukungan orang tua & & & \\
\hline
\end{tabular}


Jurnal Bosaparis: Pendidikan Kesejahteraan Keluarga

Volume 10, Nomor 1, Maret 2019

kategori positif lebih banyak dibandingkan t-skor dengan kategori negatif, maka variabel context memiliki kategori positif $(+)$.

Berdasarkan hasil evaluasi input menggunakan kuadran glickman, diperoleh hasil sesuai tabel 2 berikut ini. kategori negatif lebih banyak dibandingkan t-skor dengan kategori positif, maka variabel process memiliki kategori negatif ().

Berdasarkan hasil evaluasi product menggunakan kuadran glickman, diperoleh hasil sesuai tabel 4 berikut ini.

Tabel 2 Hasil Evaluasi Input

\begin{tabular}{|c|c|c|c|c|}
\hline \multirow{2}{*}{ Variabel } & \multirow{2}{*}{ Indikator } & \multicolumn{2}{|c|}{ t-skor } & \multirow[t]{2}{*}{ Hasi } \\
\hline & & Positif & Negatif & \\
\hline \multirow{3}{*}{ Input } & $\begin{array}{l}\text { Kesungguhan siswa } \\
\text { menerima pembelajaran }\end{array}$ & \multirow{3}{*}{39} & \multirow{3}{*}{38} & \multirow{3}{*}{+} \\
\hline & $\begin{array}{l}\text { Media/sumber mengajar } \\
\text { guru }\end{array}$ & & & \\
\hline & $\begin{array}{l}\text { Kelengkapan sarana dan } \\
\text { prasarana }\end{array}$ & & & \\
\hline
\end{tabular}

Berdasarkan tabel 2 di atas, diperoleh hasil bahwa hasil t-skor dengan kategori positif berjumlah 39 orang dari 75 orang responden sedangkan t-skor dengan kategori negatif berjumlah 38 orang dari 75 orang responden. Berdasarkan hasil tersebut, karena jumlah t-skor dengan kategori positif lebih banyak dibandingkan t-skor dengan kategori negatif, maka variabel input memiliki kategori positif $(+)$.

Berdasarkan hasil evaluasi process menggunakan kuadran glickman, diperoleh hasil sesuai tabel 3 berikut ini.
Berdasarkan tabel 4 di bawah ini, diperoleh hasil bahwa hasil t-skor dengan kategori positif berjumlah 38 orang dari 75 orang responden sedangkan t-skor dengan kategori negatif berjumlah 39 orang dari 75 orang responden. Berdasarkan hasil tersebut, karena jumlah t-skor dengan kategori negatif lebih banyak dibandingkan t-skor dengan kategori positif, maka variabel product memiliki kategori negatif ().

Berdasarkan hasil evaluasi outcome menggunakan kuadran glickman,

Tabel 3 Hasil Evaluasi Process

\begin{tabular}{|c|c|c|c|c|}
\hline \multirow{2}{*}{ Variabel } & \multirow{2}{*}{ Indikator } & \multicolumn{2}{|c|}{ t-skor } & \multirow[t]{2}{*}{ Hasil } \\
\hline & & Positif & Negatif & \\
\hline \multirow{3}{*}{ Process } & $\begin{array}{l}\text { Manajemen pengelolaan } \\
\text { usaha boga }\end{array}$ & \multirow{3}{*}{34} & \multirow{3}{*}{41} & \multirow{3}{*}{ - } \\
\hline & $\begin{array}{l}\text { Administrasi pengolahan, } \\
\text { penjualan produk }\end{array}$ & & & \\
\hline & $\begin{array}{l}\text { Pemanfaatan sarana dan } \\
\text { prasarana yang diberikan } \\
\text { pihak sekolah }\end{array}$ & & & \\
\hline & \multicolumn{4}{|c|}{ Tabel 4 Hasil Evaluasi Product } \\
\hline \multirow{2}{*}{ Variabel } & \multirow{2}{*}{ Indikator } & \multicolumn{2}{|c|}{ t-skor } & \multirow[t]{2}{*}{ Hasil } \\
\hline & & Positif & Negatif & \\
\hline \multirow{3}{*}{ Product } & Jenis-jenis olahan kue & \multirow{3}{*}{38} & \multirow{3}{*}{39} & \multirow{3}{*}{-} \\
\hline & Pengemasan & & & \\
\hline & Hasil penjualan produk & & & \\
\hline
\end{tabular}

Berdasarkan tabel di atas, diperoleh hasil bahwa hasil t-skor dengan kategori positif berjumlah 34 orang dari 75 orang responden sedangkan t-skor dengan kategori negatif berjumlah 41 orang dari 75 orang responden. Berdasarkan hasil tersebut, karena jumlah t-skor dengan diperoleh hasil sesuai tabel 5 berikut ini.

Berdasarkan tabel di atas, diperoleh hasil bahwa hasil t-skor dengan kategori positif berjumlah 41 orang dari 75 orang responden sedangkan t-skor dengan kategori negatif berjumlah 34 orang dari 75 orang responden. Berdasarkan hasil

Tabel 5 Hasil Evaluasi Outcome

\begin{tabular}{|c|c|c|c|c|}
\hline \multirow{2}{*}{ Variabel } & \multirow{2}{*}{ Indikator } & \multicolumn{2}{|c|}{ t-skor } & \multirow[t]{2}{*}{ Hasil } \\
\hline & & Positif & Negatif & \\
\hline Outcome & $\begin{array}{l}\text { Jenis-jenis olahan kue } \\
\text { Hasil penjualan produk }\end{array}$ & 41 & 34 & + \\
\hline
\end{tabular}


tersebut, karena jumlah t-skor dengan kategori positif lebih banyak dibandingkan t-skor dengan kategori negatif, maka variabel outcome memiliki kategori positif $(+)$.

Berdasarkan hasil evaluasi yang telah diperoleh menggunakan kuadran glickman diperoleh hasil sesuai tabel 6 berikut ini. dilingkungan sekolah saja. Dalam hal ini untuk meningkatkan hasil penjualan produk manajemen pemasaran dan pengemasan produk perlu diperbaiki seperti pemasaran produk secara online pengemasan produk lebih keatif dan inovatif sehingga hal tersebut dapat membantu meningkatkan hasil penjualan produk, dapat mencapai target penjualan serta tujuan pengelolaan

Tabel 6 Hasil Evaluasi Context, Input, Process, Product, Outcome

\begin{tabular}{llccc}
\hline No & Variabel & Positif & Negatif & Hasil \\
\hline 1 & Context & 40 & 35 & + \\
\hline 2 & Input & 39 & 38 & + \\
\hline 3 & Process & 34 & 41 & - \\
\hline 4 & Product & 38 & 39 & - \\
\hline 5 & Outcome & 41 & 34 & + \\
\hline & & & & Cukup Efektif \\
\hline
\end{tabular}

Berdasarkan hasil tabel di atas, diperoleh hasil bahwa variabel memiliki 3 tanda positif/tinggi (context, input, dan outcome) dan 2 tanda negatif/rendah (process dan product). Karena hasil variabel context, input, process, product, dan outcome bernilai tinggi, tinggi, rendah, rendah, tinggi $(++-++)$, maka terdapat pada kuadran II. Hal ini menunjukkan bahwa program pelaksanaan pengelolaan usaha boga di SMK Negeri 5 Denpasar berada dalam kategori cukup efektif.

\section{PEMBAHASAN}

Berdasarkan hasil penelitian di atas, baik data hasil wawancara, studi dokumen dan penyebaran kuesioner diketahui bahwa pelaksanaan pengelolaan usaha boga di SMK Negeri 5 Denpasar dilihat dari segi context, input, dan outcome termasuk dalam kategori efektif. Namun apabila dilihat dari segi process dan product pelakanaan pengelolaan usaha boga termasuk dalam kategori tidak efektif hal ini terjadi karena menemui beberapa kendala yang dihadapi beberapa siswa saat pelaksanaannya. Kendala-kendala yang dihadapi oleh siswa seperti kegagalan dalam pembuatan produk karena pengolahan yang kurang teliti, penyajian serta pengemasan yang kurang menarik minat konsumen untuk membeli produk yang dijual. Pemasaran hasil produksi pengelolaan usaha boga hanya usaha boga dapat terealisasikan dengan baik. Demikian juga didukung oleh, penelitian Suarjana Nyoman, Universitas Pendidikan Ganesha tahun 2015 dengan judul Evaluasi Pelaksanaan Program Pusat Kegiatan Belajar Masyarakat (PKBM) di Kecamatan Gerokgak Kabupaten Buleleng, berdasarkan hasil data menunjukkan hasil evaluasi terhadap penyelenggaraan program PKBM di kecamatan Gerokgak dengan menggunakan evaluasi program model CIPP diperoleh hasil sangat efektif.

Berdasarkan hasil perhitungan menggunakan teori Glickman di atas, diperoleh hasil variabel context pengelolaan usaha boga di SMK Negeri 5 Denpasar bernilai positif (+) yang artinya variabel context sudah sangat efektif dalam penerapannya. Hal ini didukung oleh hasil wawancara yang menunjukkan bahwa program pelaksanaan pengelolaan usaha boga merupakan salah satu pembelajaran yang sudah tercantum dalam mata pelajaran di sekolah. Pada mata pelajaran pengelolaan usaha boga siswa diajarkan untuk dapat berwirausaha. Oleh karena itu, dalam perencanaan pembelajarannya tidak hanya teori yang diberikan, namun praktik pelaksanaan pengelolaan usaha boga juga diberikan kepada siswa. Kebijakan ini telah mendapat dukungan dari sekolah maupun dari orang tua siswa. Selain hal tersebut di atas juga didukung oleh teori evaluasi context menurut Suharsimi Arikunto (2014), menyatakan bahwa evaluasi context 
adalah bertujuan untuk membantu mengambil keputusan dalam perencanaan yaitu yang mencangkup tentang mata pelajaran pengelolaan usaha boga, dukungan sekolah dan dukungan orang tua siswa. Demikian juga didukung oleh, penelitian Fitria Ariza, Universitas Negeri Yogyakarta tahun 2016 dengan judul Evaluasi Pelaksanaan Pembelajaran Keterampilan Tata Boga Di SMA-LB BC Kepajen Malang, berdasarkan hasil data menunjukkan dilihat dari hasil segi context tujuan pelaksanaan keterampilan tata boga di SMA-LB BC Kepajem dapat tercapai dengan menggunakan evaluasi program model CIPP diperoleh hasil baik. Selain didukung penelitian dari Fitria Ariza juga didukung dari data hasil wawancara dan penyebaran kuesioner dapat disimpulkan bahwa sudah sesuai dengan teori-teori yang ada pada kajian teori.

Berdasarkan hasil perhitungan evaluasi input menggunakan teori glickman, diperoleh hasil positif (+) yang menunjukkan bahwa evaluasi input sangat efektif dalam penerapannya. Hal ini juga didukung oleh hasil wawancara kepada siswa kelas XII berkaitan dengan variabel input bahwa siswa bersungguh-sungguh dalam menerima pembelajaran. Selain itu media/sumber mengajar yang digunakan guru sudah baik sehingga memudahkan siswa dalam menerima informasi. Sarana dan prasarana yang diperlukan dalam praktik pengelolaan usaha boga sudah memadai, sehingga memudahkan siswa dalam menerapkan teori yang telah dipelajari melalui praktik yang dilaksanakan. Demikian juga didukung oleh, penelitian Fitria Ariza, Universitas Negeri Yogyakarta tahun 2016 dengan judul Evaluasi Pelaksanaan Pembelajaran Keterampilan Tata Boga Di SMA-LB BC Kepajen Malang, berdasarkan hasil data menunjukkan dilihat dari hasil segi input sarana prasarana laboratoium Tata Boga telah memenuhi standar yang ditetapkan oleh PERMEN Depdiknas Nomor 40 Tahun 2008 sehingga dikatakan layak dengan menggunakan evaluasi program model CIPP diperoleh hasil baik. Selain didukung penelitian dari Fitria Ariza juga didukung dari hasil data yang diperoleh dari wawancara yang dilakukan dengan siswa, dan penyebaran kuesioner disimpulkan bahwa data yang diperoleh sudah sesuai dengan teori yang dikembangkan oleh Suharsimi Arikunto (2014) menyatakan evaluasi input adalah evaluasi yang bertujuan untuk membantu dalam pengambilan keputusan dalam hal strukturisasi. Input dalam penelitian ini ada dua yaitu siswa, sarana dan prasarana yang disediakan oleh pihak sekolah untuk menunjang pelaksanaan pengelolaan usaha boga.

Berdasarkan hasil perhitungan
evaluasi process mengunakan teori Glickman, diperoleh hasil negatif (-) yang menunjukkan bahwa evaluasi process tidak efektif dalam penerapannya. Hal ini juga didukung oleh hasil wawancara kepada siswa kelas XII berkaitan dengan variabel process bahwa masih ada beberapa kendala dalam program pelaksanan pengelolaan usaha boga di SMK Negeri 5 Denpasar. Salah satunya pada saat pembuatan produk yang mengalami kesalahan sehingga harus mengulang pembuatannya sampai berhasil. Pengemasan produk juga sempat mengalami kesalahan sehingga harus dikonsultasikan kepada guru agar dapat segera diperbaiki.

Selain itu, masih belum efektifnya variabel process dalam pelaksanaan usaha boga didukung oleh hasil studi dokumen yang menunjukkan bahwa hasil penjualan produk tidak mencapai target penjualan yang telah ditetapkan sebelumnya. Target penjualan produk siswa kelas XII Jasa Boga sebelumnya ditetapkan sebesar $R p$ 14.850.000, namun realisasi yang bisa diwujudkan dari hasil penjualan sebesar $\mathrm{Rp}$ 10.607.500. Hal ini bertentangan dengan teori usaha boga yang menjelaskan bahwa usaha boga dapat berupa komersil ataupun semi komersil, yaitu dengan mengambil untung sebesar-besarnya atau mengambil untung yang tidak terlalu besar namun dapat menutupi biaya-biaya yang harus dikeluarkan pihak pengelola. Dengan adanya realisasi yang tidak sesuai target, maka pihak pengelola belum dapat mewujudkan teori usaha boga. Hal tersebut menjelaskan bahwa, sebisa mungkin dalam melakukan usaha boga menghindari adanya kerugian pihak 
pengelola sehingga bisa melaksanakan usahanya secara berkesinambungan dalam waktu yang panjang.

Belum tercapainya target penjualan dapat disebabkan beberapa hal di antaranya pemasaran produk yang kurang baik, pengemasan produk yang kurang menarik, maupun kesalahan yang terjadi dalam proses pembuatan produk. Hal ini sesuai dengan pendapat Tjiptono (2008) yang menyatakan bahwa promosi merupakan salah satu faktor penentu keberhasilan suatu program pemasaran. Promosi adalah suatu bentuk komunikasi pemasaran, yaitu aktivitas pemasaran yang berusaha menyebarkan informasi, mempengaruhi atau membujuk, dan atau mengingatkan pasar sasaran atas perusahaan dan produknya agar bersedia menerima, membeli, dan loyal pada produk yang ditawarkan perusahaan yang bersangkutan. Promosi dapat dilakukan dengan menyebar pamflet, ataupun melalui media online untuk menginformasikan kepada khalayak luas.

Selain promosi, kemasan produk juga sangat penting diperhatikan untuk menarik minat pembeli. Hal ini sesuai dengan pendapat Daryanto (2011) yang menyatakan bahwa, membuat bungkus agar menarik pembeli maka perusahaan harus mempertimbangkan dari berbagai aspek baik aspek ekonomis, keindahan maupun praktisnya. Desain kemasan packaging merupakan salah satu strategi pemasaran yang menjadi andalan para pemasar. Kemasan sebagai salah satu ujung tombak pemasaran bukan sekedar bungkus, tetapi bagian dari consumer touching point yang mengkomunikasikan poisitioning dan diferensiasi produk serta mampu menciptakan impulse buying (Harminingtyas, 2013). Demikian juga hal ini didukung oleh penelitian Edwindhana Mareza Putra, Universitas Negeri Semarang tahun 2015 dengan judul Evaluasi Pelaksanaan Program Bimbingan dan Konseling Di SMK Negeri 1 Blora (Model CIPP), berdasarkan hasil data penelitian menunjukkan hasil evalasi pada komponen context, input dan proses berada pada kategori cukup baik. Simpulan dari penelitian ini bahwa evaluasi pelaksanaan program bimbingan dan konseling di SMK Negeri 1 Blora dengan model evaluasi CIPP berada pada kategori cukup baik.

Berdasarkan hasil perhitungan kuesioner dengan teori glickman, diperoleh hasil variabel product bertanda negatif (-), yang artinya product (hasil) dari pelaksanaan pengelolaan usaha boga tidak efektif. Hal ini didukung oleh hasil wawancara yang telah dilakukan kepada siswa yang menunjukkan bahwa masih terdapat beberapa kendala dalam pembuatan produk. Kendala tersebut dapat berupa kurang teliti dalam pengolahan produk seperti penimbangan bahan, pengunaan peralatan yang kurang tepat, kemasan yang masih kurang menarik minat konsumen sehingga penjualan hasil produk masih belum mampu mencapai target yang telah ditetapkan. Siswa telah menjual produk olahan kue seperti bolu karamel, kue sus, kue putri ayu, donat kentang, pisang keju coklat, puding marmer dan lain sebagainya. Meskipun siswa telah berhasil membuat produk sesuai aturan dan resep yang ada, namun masih perlu memperhatikan hal-hal yang menunjang minat pembeli terhadap produk seperti kemasan produk dan keunikan produknya. Siswa masih perlu mencari banyak referensi sehingga mendapatkan ide untuk mengkreasikan produk dan menjadikannya berbeda dengan produk lain yang sejenis, guna menarik minat konsumen. Seperti memberikan diskon untuk pembelian produk tertentu. Hal lain yang dapat dilakukan yaitu dengan memberikan nama unik pada produk olahan kue sehingga mudah diingat oleh pembeli dan menarik pembeli untuk mengetahui rasa dari produk yang telah dibuat. Memberikan varian rasa yang berbeda juga dapat dilakukan oleh siswa sehingga menarik pembeli untuk mencoba beberapa varian rasa sehingga pembelian dapat meningkat. Hal ini lah yang akan menjadikan produk banyak diminati konsumen, sehingga target penjualan dapat tercapai.

Demikian juga didukung oleh, penelitian Fitria Ariza, Universitas Negeri Yogyakarta tahun 2016 dengan judul Evaluasi Pelaksanaan Pembelajaran Keterampilan Tata Boga Di SMA-LB BC 
Kepajen Malang, berdasarkan hasil data menunjukkan dilihat dari hasil segi product penjualan produk boga dari SMA-LB BC Kepanjen tidak dapat terlaksana dengan baik hal ini dikarenakan masyarakat kurang mengapresiasi produk boga yang dihasilkan siswa SLB. Kurangnya apresiasi masyarakat terhadap produk boga yang dibuat oleh siswa SLB membuat produk yang dijual tidak laku dan mengalami kerugian. Oleh karena itu SMA-LB Kepanjen memtuskan untuk tidak menjual hasil keterampilan.

Berdasarkan hasil perhitungan kuesioner dengan teori glickman, diperoleh hasil variabel outcome bertanda positif $(+)$, yang artinya outcome (dampak) dari pelaksanaan pengelolaan usaha boga sudah efektif. Dengan adanya pembelajaran pengelolaan usaha boga dapat menimbulkan jiwa wirausaha siswa. Hal ini didukung oleh hasil wawancara yang menyatakan bahwa siswa sangat termotivasi dengan adanya program pengelolaan usaha boga karena siswa dapat belajar cara untuk berwirausaha yang baik dan benar, baik dari proses pembuatan hingga pemasarannya. Selain hal tersebut di atas juga didukung oleh teori menurut Suharsimi Arikunto (2014) yang menyatakan bahwa evaluasi terhadap dampak setelah mengikuti pembelajaran pengelolaan usaha boga banyak memberikan manfaat bagi setiap siswa berupa pengalaman berwirausaha. Berdasarkan hasil yang diperoleh melalui wawancara, studi dokumen dan penyebaran kuesioner sudah sesuai dengan teori yang ada tentang evaluasi outcome atau dampak.

Hasil perhitungan kuesioner dengan teori Glickman, dan analisis data dari variabel context, input, process, product dan outcome terhadap pelaksanaan pengelolaan usaha boga di SMK Negeri 5 Denpasar ditemukan bahwa variabel context tergolong efektif, varibel input tergolong efektif, variabel process tergolong tidak efektif, variabel product tergolong tidak efektif, dan variabel outcome tergolong efektif. Berdasarkan hasil temuan tersebut, context, input, process, product dan outcome adalah positif, positif, negatif, negatif, positif $(++-$
- +) maka terdapat pada kuadran II sesuai dengan paradigma pengkategorian pelaksanaan pengelolaan usaha boga. Hal ini menunjukkan bahwa program pelaksanaan pengelolaan usaha boga di SMK Negeri 5 Denpasar berada dalam kategori cukup efektif.

\section{SIMPULAN DAN SARAN}

Berdasarkan hasil penelitian dan pembahasan, dapat disimpulkan bahwa, (1) Pelaksanaan pengelolaan usaha boga pada siswa kelas XII SMK Negeri 5 Denpasar terdiri dari empat tahap, yaitu tahap persiapan (bahan, peralatan), tahap pengolahan, tahap pengemasan/penyajian, pemasaran produk. Tahap persiapan bahan dan peralatan praktik dilakukan oleh guru dan siswa agar peralatan yang digunakan benar dan lengkap. Pada tahap pengolahan dan pengemasan/penyajian sampai tahap pemasaran semua dilakukan oleh siswa agar siswa paham bagaimana cara mengelola sebuah usaha agar dapat memperoleh keuntungan yang diinginkan sesuai dengan tujuan untuk melakukan wirausaha. (2) Hasil perhitungan dan analisis data dari variabel context, input, process, product dan outcome terhadap pelaksanaan pengelolaan usaha boga ditemukan bahwa variabel context tergolong efektif, varibel input tergolong efektif, variabel process tergolong tidak efektif, variabel product tergolong tidak efektif, dan variabel outcome tergolong efektif. Berdasarkan hasil temuan ini, context, input, process, product dan outcome adalah positif, positif, negatif, negatif, positif $(++--+)$ maka dari itu hasil penelitian ini adalah "pelaksanaan pengelolaan usaha di SMK Negeri 5 Denpasar cukup efektif".

Berdasarkan simpulan tersebut, Dalam proses pelakanaan pengelolaan usaha boga diharapkan siswa lebih bersungguhsungguh dalam mengikuti pelajaran pengelolaan usaha boga agar tujuan dari pembelajaran pengelolaan usaha boga dapat tercapai dengan baik. Pembuatan produk harus diperhatikan secara mendetail mulai dari cita rasa hingga pengemasan produk agar dapat menarik 
Jurnal Bosaparis: Pendidikan Kesejahteraan Keluarga

Volume 10, Nomor 1, Maret 2019

minat konsumen serta pemasaran produk perlu diperluas lagi.

\section{UCAPAN TERIMAKASIH}

Selesainya artikel penelitian ini tidak luput dari bimbingan yang telah diberikan. Oleh karena itu, diucapkan terimakasih kepada kedua dosen pembimbing yaitu Cokorda Istri Raka Marsiti, S.Pd., M.Pd. selaku dosen pembimbing I dan Luh Masdarini, S.Pd., M.Pd. sebagai dosen pembimbing II.

\section{DAFTAR RUJUKAN}

Arikunto, Suharsimi \& Cepi Safruddin Abdul Jabar. 2014. Evaluasi Program Pendidikan Pedoman Praktis Bagi Mahasiswa dan Praktisi Pendidikan. Cetakan kelima. Jakarta: PT. Bumi Aksara.

Daryanto. 2011. Manajemen Pemasaran: Sari Kuliah. Bandung : Satu Nusa.

Edwindhana Mareza Putra. 2015. Evaluasi Pelaksanaan Program Bimbingan dan Konseling di SMK Negeri 1 Blora (Moel CIPP). Semarang: Jurusan Bimbingan dan Konseling, Fakultas Ilmu Pendidikan, Universitas Negeri Semarang. Journal unnes, UGC, Volume 4 Nomor 1 Tahun 2015.
Fitria Ariza. 2016. "Evaluasi Pelaksanaan Pembelajaran Keterampilan Tata Boga di SMA-LB BC Kepajen Malang". Jurnal UNY. Vol.1.2016.

Harminingtyas, Rudika. 2013. "Analisis Fungsi Kemasan Produk Melalui Modal View dan Pengaruhnya Terhadap Keputusan Pembelian Konsumen pada Produk Rokok Kretek Dji Sam Soe di Kota Semarang". Jurnal STIE Semarang. Vol.2, No.5

Saraswati, Endah. 2016. Guru Pembelajar Modul Paket Keahlian Jasa Bog Sekolah Menengah Kejuruan. Jakarta : Kementrian Pendidikan dan Kebudayaan.

Suarjana, Nyoman. 2015. Evaluasi Pelaksanaan Program, Pusat Kegiatan Belajar Masyarakat (PKMB) Di Kecamatan Gerokgak Kabupaten Buleleng. Singaraja: Program Studi Pendidikan Dasar, Program Pascasarjana, Universitas Pendidikan Ganesha. E-Journal Program Pascasarjana, Volume 5 Tahun 2015.

Tjiptono, Fandy. 2008. Strategi Pemasaran. Edisi 3. Yogyakarta : ANDI. 